\title{
Russian law in the early modern period
}

\section{Muravyeva, Marianna Georgievna}

Oxford University Press

2018-07-19

Muravyeva, M G 2018 , Russian law in the early modern period . in H Pihlajamäki \& M D

Dubber (eds), The Oxford Handbook of European Legal History . Oxford University Press, Oxford , pp. 854-875 . https://doi.org/10.1093/oxfordhb/9780198785521.013.36

http://hdl.handle.net/10138/332480

https://doi.org/10.1093/oxfordhb/9780198785521.013.36

acceptedVersion

Downloaded from Helda, University of Helsinki institutional repository.

This is an electronic reprint of the original article.

This reprint may differ from the original in pagination and typographic detail.

Please cite the original version. 


\section{RUSSIAN LAW IN THE EARLY MODERN PERIOD}

Marianna Muravyeva

\section{Russian Legal Modernity: Autocracy and Legal Development}

Russian early modern legal history lies at the foundation of modern law, and provides a pathway into modernity both via legal theory and emerging legal tradition. In the late fifteenth century, the Grand Principality of Muscovy became a centre for the new, gradually centralizing, state shaking off the Mongol-Tatar yoke and firmly establishing its rule over neighbouring smaller principalities and citystates. Muscovy emerged as a successor to Kievan Rus' and medieval Vladimir-Suzdal' Rus', although bitterly partitioned and sunk into feudal wars. However, it managed to continue its commitment to older laws such as the Russian Law of the eleventh-century (Russkaia Pravda), but was also open to the reception of Roman law via the incorporation of Byzantine legal codes into canon and civil law.

There are several important frameworks for legal development in the sixteenth, seventeenth and eighteenth centuries. Autocracy and the absolutist state frame the relationships between an individual and the state as well as between the public law and political background for other legal developments. Centralisation and geographical expansion provide a spatial framework for a variety of legal jurisdictions. Serfdom and the transformation of the late feudal economy into a proto-market economy impacted private law with new forms of property relationships and ownership. The slow incorporation of the church into the state machinery brought about a restricted moral order and ritualised control over private life. All these frameworks and processes reflected an uneasy and complicated modernisation, that for Russia meant further participation in coining European legal tradition.

The main early modern political framework - autocracy (samoderzhavie) - is believed to be part of the heritage of Mongol despotism. ${ }^{1}$ First, Muscovy rulers attempted to create a centralized bureaucracy by eliminating the independence of princes from ex-independent principalities and high nobility (boyarstvo), and establish service nobility (dvorianstvo) personally tied to the Tsar. Ivan IV (15331584) and Peter I (1682-1725) conducted profound social reforms to this purpose. The bureaucratic system of chancelleries (prikazy) which emerged took control over major spheres of social life and

\footnotetext{
${ }^{1}$ William Butler, Russian Law (OUP 2009) 23.
} 
performed the state's functions, with justice being a universal privilege and the responsibility of every department. The chancelleries were staffed by full-time, generally hereditary clerks, schooled from childhood through practical, on-the-job training. The Muscovite autocracy, though, relied on representative institutions, such as the Land Assembly, to provide a space for negotiation and consensus. The Tsar also had the Boyar Council (Duma) acting as a council of state with wide political and administrative powers including judicial powers. Appointments to the council were based on the system of aristocratic lineage seniority (mestnichestvo). The Tsar appointed governors (voevody) as regional head officials empowered with administrative and judicial functions, but who were personally responsible to the Tsar. ${ }^{2}$

The ideological support was provided by the 'Moscow-Third Rome' concept that cemented the Moscow tsars' claims for legitimacy and absolute power due to their 'true' Orthodox commitment. The Tsar claimed his 'divine right' to rule, becoming the sole source of power and justice. Every administrative institution and official served in his name; thus, all the legal documents (laws, complaints, petitions, reports, and so on) were done in his name. Patrimonialism and paternalism sealed the bond between the Tsar and the people, creating a system of personalized autocracy. ${ }^{3}$ The tsars worked towards a social and professional sensitive concept of justice in which equity was ensured through the concept of the substantive understanding of (in)equality.

By the eighteenth century, this system had evolved into its 'absolutist' phase with Peter the Great's attempt to reform the monarch's image which became a new source of legitimization for the monarch's power. Personalised autocracy gave way to the idea of the general welfare, ensuring the economic wellbeing, security and happiness of the citizenry. One of the principal components of this 'enlightenment absolutism' was a long effort to establish legality (zakonnost') as the basis of the operations of the state and secure legal justice (pravosudie) based on formalized approaches to equity. ${ }^{4}$

\footnotetext{
${ }^{2}$ Peter B. Brown, 'How Muscovy Governed: Seventeenth-Century Russian Central Administration’ (2009) 36 Russian History 459-529.

${ }^{3}$ Valerie Kivelson, 'Merciful Father, Impersonal State: Russian Autocracy in Comparative Perspective' (1997) 31 Modern Asian Studies 635-663.

${ }^{4}$ Richard Wortman, The development of a Russian legal consciousness (University of Chicago Press 2010) ch. 2 (hereafter Wortman, Russian legal consciousness).
} 
To ensure the ruler's primary role as a source of justice, the state worked towards consolidation of law and creating universal legal spaces for administering justice and ensuring social consensus. Alongside other early modern states, Russia headed towards monopolising justice operations and punishment systems to ensure its dominance in administering justice. Between the sixteenth and eighteenth counties, Russian laws were under constant revision and codification. By the early sixteenth century, Muscovy had a complex system of laws inherited from the Kievan period, and a variety of lands which were now part of Muscovite state. The Russian Law (Russkaia Pravda) of the eleventh century remained a major source of law, with the first universal legal code Sudebnik (code of law) of 1497 borrowing twenty-five articles from it. The revised versions of 1550 and 1589 reflected the changes in connection with the enhanced status of the Tsar and further centralisation of power. ${ }^{5}$

Sudebniki served as an advisory to judges, setting fees for services, decreeing punishments for crimes and setting out procedural rules and standards of evidence. In the course of their revision, sudebniki incorporated decrees on landholding, debts, enserfment, and developed the inquisitorial procedure. The later editions and the composite version (svodnyi sudenbnik) of 1606 were divided into thematic chapters and had a cross-reference system that made it easier for judges to use. ${ }^{6}$ In addition to sudebniki, chancelleries had their own 'charter books' (ustavnye knigi) that included specific procedures for the chancelleries' jurisdictions, as for example in the case of the Felony Chancellery (Razboinyi prikaz): its charter books of 1555-6 and 1616 outlined investigation procedures, rules of evidence, prosecution and punishment.

The major codification landmark of the era was the 1649 Conciliar Legal Code (Ulozhenie) that served as a main and universal code of law until as late as 1830. The Ulozhenie was the first code issued in print together with the codex juris canonici of the Orthodox Church called Kormchaia kniga (Pilot (Leading) Book) in 1650-1652. This code included twenty-five thematic chapters and 967 articles that regulated all legal spheres. ${ }^{7}$ The Kormchaia supplemented the Ulozhenie with its jurisdiction over ecclesiastical matters and family law. These two remained as major sources of law during the second half of the seventeenth and eighteenth centuries.

\footnotetext{
${ }^{5}$ Peter B. Brown, 'Neither Fish nor Fowl: Administrative Legality in Mid-and Late-Seventeenth-Century Russia' (2002) 1 Jahrbücher für Geschichte Osteuropas 1-21.

${ }^{6}$ George G. Weickhardt, 'The Composite Law Code of 1606' (2006) 33 Russian History 1-18.

7 Richard Hellie, 'Early Modern Russian Law: The Ulozhenie of 1649’ (1998) 15 Russian History 155-179.
} 
Post-Ulozhenie legislation took the form of the tsar's and the government's decrees and ordinances that aimed at filling legislation gaps and the regulation of public order. They were in line with various compendia of laws such as the Newly Promulgated Articles of 1669, which was a revised criminal legislation, and also included tariff and trade regulations, a variety of public order regulations, and so on. Following the tradition of personal decrees, Peter I continued this 'manual' management of the state. However, Peter sought to establish a new universal code and created a Legislative Commission for this purpose in 1703, but failed to carry it through. But he did introduce the new military code in 1716 to serve the purposes of the militarized service nobility. The Legislative Commission, though, continued its work in systematizing existing law and producing several draft codes, none of which came to be officiated. However, this constant legislative systematization that continued for the major part of the eighteenth century contributed to the development of legislation techniques and provided compendia from which judges and other practitioners could work.

Russian substantive law saw significant changes during the sixteenth, seventeenth and eighteenth centuries. It transformed under the influences of late feudal economics, serfdom, and the slow emergence of proto-market relations. The majority of litigation during this period belonged to the private sphere of litigation over transactions, property and other private matters. Individuals, families, communities and various types of entities participated in private transactions to conduct trade agreement, contracts, acquire property, different social status and so on. However, social inequalities and serfdom profoundly influenced civil law as to the personal status of an individual and property relationships. Contract law, property law, inheritance, family law and transactions were developing actively during this period towards a more individualised protection for those who belonged to the upper classes. The Sudebniki of the fifteenth and sixteenth century as well as the Ulozhenie of 1649 regulated in detail every estate (nobility, service class, clergy, townsmen, peasants, serfs) and their relations with each other and the state; they established comprehensive rules of property, service and servitude.

However, due to serfdom, the category of personal rights did not develop properly until the nineteenth century. Individuals continued to think in terms of the categories of privilege and status, but their relationship with the state evolved from 'slaves', as they called themselves in the seventeenth century, 
to 'subjects', as Catherine II decreed that everyone in the Empire was to be called. The state gradually introduced a universe of obligations and duties so that by the 1760s the idea of service was firmly embedded in all social groups. The Ulozhenie of 1649 shackled the nobility and service class with service and with restrictions on the transfer of their hereditary estates and service lands. The townsmen were bound to their taxpaying collectives and were levied with taxes. Peasants were bound to the land. ${ }^{8}$

The state firmly monopolised violence and transformed into a police state. ${ }^{9}$ Russian criminal law evolved from a private type of justice to the state controlled criminal justice system, with the main focus on crime as a socially dangerous deed to be punished according to its degree of harm. From the beginning of the sixteenth century, the scope of criminal law became clearly specified and focused on crimes against the state, church, public peace, property and the individual. Criminal liability gradually became individual instead of collective, a concept which was firmly established by the eighteenth century.

\section{The Legal Geography of Muscovy and Russian Empire}

By the late fifteenth century the Grand Prince of Muscovy had managed to assert his authority over neighbouring princes and city-states in Central and Western Russia. Even then, compared to other European states, Muscovy was a large country. The Princes gradually fashioned the centralized state, and as the Grand Prince's authority extended over newly acquired provinces, charters were issued to confirm the relationship to Muscovy or to grant special privileges to certain communities. Ivan III (1562-1502), his son Vasili (Basil) III (1505-1533) and, finally, Ivan IV (1533-1584) conducted expansion policies to acquire even more lands towards the East that resulted in the acquisition of Kazan' in 1552 and further expansion into the middle-Volga and steppe. This expansion was in full swing by the seventeenth century, with fortified frontier outposts staffed not only by Russians but also by elites of the Tatar, Mari, Mordva and other indigenous people. With the further expansion into Siberia, Russia acquired even more indigenous populations while attempting to re-settle Russians from the Western and Northern parts of the country into Siberia. In 1547 Ivan IV assumed the title of the

\footnotetext{
${ }^{8}$ Valerie Kivelson, ‘Muscovite “Citizenship”: Rights without Freedom' (2002) 74 The Journal of Modern History 465-489; Eric Lohr, 'Russian Citizenship: Modernization and Population Policy in Historical Perspective' (2013) 60 Problems of Post-Communism 3-15.

${ }^{9}$ Marc Raeff, The Well-ordered police state: social and institutional change through law in the Germanies and Russia, 1600-1800 (Yale University Press 1983).
} 
'Tsar of All the Russians' to signify a change from a Principality into a Tsardom with elements of the empire until Peter I (1682-1725) officially proclaimed Russia as a/the Russian Empire by assuming the title of emperor in 1721.

Faced with the complex ethnical and spatial composition of the country, Russian rulers proceeded with centralized policies for governing those lands, but granted the newcomers the privilege to retain their own laws and jurisdiction unless Russian settlers and officials were involved. The same principle worked for the Western territories conquered during the seventeenth and eighteenth centuries. Estland, Livland, Finland, Ukraine, and Poland retained their previous legal statutes for regulating relationships locally. The difference was that because Russia belonged to the Roman law tradition and accepted many laws and legal ideas from other European countries, the differences between Russian law and that of its western lands was rather technical; the differences mostly concerned the length of the inflicted punishment. With its eastern populations, Russia had to oversee conceptual differences in understanding the whole idea of what was legal, criminal, or customary. Thus, many indigenous populations of the steppe and Siberia followed the Mongolian Oirat laws, codified in 1640, that included civil and criminal law with its heavy focus on property relations in nomadic settings, marriage, and kinship. ${ }^{10}$

The administration of justice for the indigenous people - unless it involved Russians - was left in the hands of local chiefs, who ruled according to their own laws. The government repeatedly reminded local officials 'not to try any cases involving natives'. Many of the 'natives', however, preferred to receive justice from Russians. They petitioned voevodas (governors) with cases involving murders, the purchase price of their wives, sorcery, robbery, and grievances of all sorts. The voevodas were willing to try these cases, because in doing so they saw a chance of weakening the influence of local chiefs whose loyalty they doubted and also because they found serving as an alternative purveyor of justice to be extremely profitable. However, the voevodas still used local laws to provide most pacifying litigation for both sides.

\footnotetext{
${ }^{10}$ On the code see: Munkh-Erdene Lhamsuren, 'The 1640 Great Code: an Inner Asian parallel to the Treaty of Westphalia'
} (2010) 29 Central Asian Survey 269-288. 
To avoid confusion, between 1678 and 1685 the government settled the question of authority in the following manner: 'mixed cases' - involving both Russians and the indigenous population - cases of murder, and suits involving amounts of more than five roubles were to be judged by the voevodas alone; and suits involving amounts of five roubles or less were handled by minor officials, usually iasak (tribute) collectors. Whenever they handled local cases, they tried to give verdicts according to local customs.

In the eighteenth century, the Russian government continued to work on separate jurisdictions for indigenous populations and Russian settlers. However, the authorities preferred to cooperate with native populations rather than to assimilate them. The 1728 Instruction ordered all indigenous people to submit to their chiefs (toyans or noyans). Judicial powers were exercised by the tribal judges (shulengas). The proceedings of these courts were conducted orally, and therefore little information has survived. Theoretically speaking, all capital offences had to be brought before the Russian administration and courts, but family quarrels - including 'petty quarrels about the kalym' - and feuds were referred to the chieftains and their courts. At the same time, Russian authorities maintained the tradition of ruling cases among indigenous plaintiffs according to their respective customary law. ${ }^{11}$

Such policies created great legal diversity in the Empire, allowing more locally sensitive legislation on the one hand, but ruling to universal legal norms and standards on the other. Therefore, Russia did not have a universal national law applicable to all ethnic groups until the nineteenth century, and that factor added to the complexity of its legal situation.

\section{Reforming the Authoritarian State: Russian Justice System}

The Russian justice system has had a turbulent history. Harsh criticism of its ineffectiveness and corruption stimulated regular reforms. The Russian justice system, which was closely tied to administration reforms, was not easy to comprehend. Jurisdiction over criminal and civil cases changed during the sixteenth, seventeenth and eighteenth centuries, when the system of specialized courts

${ }^{11}$ See further: M. M. Fedorov, Pravovoe polozhenie narodov Vostochnoi Sibiri (XVII-nachalo XIX veka) (Yakutskoe knizhnoe izd-vo 1978). 
belonging to administrative bodies was transformed into a system of universal courts separate from the administration.

The pre-eighteenth century justice system exercised the principle of administrative and justice functions in administrative bodies called prikazy (chancelleries), which provided the predominance of specialized courts and a total absence of universal jurisdiction courts. This system logically suited the highly socially and ethnically differentiated Russian society, where the system of social orders (soslovia) as well as ethnic hierarchy was carefully observed. In addition, since many chancelleries had additional professional functions, the ordinary Muscovite lived in a situation of complex socioprofessional networks and had to resolve how to seek justice according to, among other things, the nature of the case and his/her social and professional status, as well as the social and professional status of the defendants and other litigants.

In all the seeming complexity of the pre-eighteenth-century justice system, two universal authorities represented the State and the Church - the governor (voevoda) and the local bishop - who were present in more or less all regions of the Muscovy State. Formally, the governor dealt with civil and criminal cases, except for crimes against religion and the Church, and exercised jurisdiction over the laity with the exclusion of the monastery peasants and the clergy. The local bishop oversaw all people living on the ecclesiastical lands and decided upon crimes against religion and the Church. These jurisdictions, however, were not strictly observed and demanded constant negotiations between the two. As a rule, in localities where both jurisdictions were available on the spot, the cases were tried according to the regular procedure: everything involving military men, officials and townsfolk went to the voevoda while all the rest went to the local archbishop. In localities (such as remote military settlements or small villages, in the far north) where one of the jurisdictions was immediately available, all the cases went to the nearest judge who then decided whether there was a need to transfer the case further.

Peter's judicial reforms were closely tied to the local administrative reform and aimed at the unification of the Russian justice system; yet they further developed the principle of socio-professional jurisdiction. The reforms were also bound to the administrative reform and reconfiguration of the geographical jurisdiction. The system he created seemed to be logical and was meant to be effective, but it did not last long and failed to adjust to the traditional means of justice. During the experimental 
stages (1707-1718), Peter tested several types of courts. In 1705 he introduced town halls (ratushi) in the cities, and in 1709, as a result of administrative reform, new regions received special land judges offices (landrichterskie kantseliarii), which dealt with criminal offences until 1718 when they were abolished.

In 1718 four court instances were created: the low (first) court instance, provincial and town courts (abolished in 1722); the second instance, hofgerichts, high courts (nadvornye sudy, abolished in 1727); and the Collegium of Justice with final appeal to the Senate. Not every region received the three instances, however: only seven big cities received the full low/high court system while thirty-nine cities were left with low courts alone. The only city with the full system appeared to be the capital, St. Petersburg, which had a low (then provincial) court and hofgericht (nadvornyi sud), supported by regional (gubernskaia) and police chancelleries dealing with the execution of justice and protection of the public peace. Moreover, the main central institutions including the Collegium of Justice and the Senate were situated in St. Petersburg, and as a result, after the abolition of the low and high courts, all criminal and civil cases went to the Collegium of Justice or often even to the Senate for ruling. ${ }^{12}$

In any case, this system of state courts ceased to exist very soon, starting in 1722, first with the substitution of low courts by regional (gubernskie) and provincial chancelleries, and then, in 1727, with the abolition of hofgerichts and transferring of the justice powers back to voevodas and governors. Parallel to the general courts the specialized courts, or rather socio-professional courts, existed and flourished. The newly founded Collegia (Kollegiia, transcribed to Russian from its Latin original Collegium), that substituted prikazy (chancelleries), all possessed some jurisdictional powers, at least over their own areas (thus, for example, the Manufacture Collegium dealt in conflicts between or involving manufacturing workers and, if necessary, transferred their cases to the other Collegia). A great number of cases came from the Estate Collegium, which dealt with lands and estates and established the validity of estate inheritance, for which purpose it was in constant correspondence with the Synod over the validity of marriages and divorces, especially involving bigamy and adultery cases. The Military Collegium continued to have jurisdiction over the military through its own system of

\footnotetext{
${ }^{12}$ See further: D. O. Serov, Sudebnaia reforma Petra I. Istoriko-pravovoe issledovanie (IKD Zertsalo-M 2009) (hereafter
} Serov, Sudebnaia reforma Petra I). 
military courts (kriegsrechts). The General Magistrate ruled over the urban population. The Synod controlled the clergy and some religious offences and so on.

Although Peter's legal reform did not produce the system he wanted, it provided the further systematization of the socio-professional courts, particularly of the two major traditional social groups - the military and the clergy. For the rest of the population it appeared that the former situation, in which the same institutions exercised both judicial and administrative functions, was reinstated. The functions of the low courts now belonged to the regional (gubernskie) and provincial chancelleries, which were originally administrative executive bodies, subordinated to the governors and voevodas respectively, to whom were also delegated the functions of hofgerichts and became the upper court instance in the regions. Magistrate institutions including the General Magistrate were also abolished and turned into simple town halls, which were also subordinate to the local governors or voevodas. From the point of view of the classic police state, the court system between 1727 and 1775 looks very pragmatic; nothing disturbed the vertical execution of the needs of the State. It was also rather familiar to the population. The court did not become independent, but the ordinary plaintiff did not consider that the independence of the court was connected to seeking justice. It was rather connected with the effectiveness and fairness of the judges, which was separate to their independent status. What emerged as a justice system was low provincial (voevodskaia), provincial (provintsial'naia), or regional (gubernskaia) chancelleries (depending on the status of the locality) together with voevodas or governors as the first judicial instance, with the possibility of appeal to the Collegium of Justice and the Senate respectively.

In this situation the role of voevodas and governors as the ultimate source of justice became crucial, thus continuing the seventeenth century tradition. They were the final recipients of all petitions, especially in cases where litigants were not satisfied with the judge's decision. However, the composition of the government of each region (gubernia) or province was far from uniform. The general composition of local administration between 1727 and 1775 was the following: the country was divided into regions (gubenia), each region into provinces (provintsia), and each province into districts (uyezd). Each administrative unit had its own head: governors were in charge of gubernia, and voevodas were in charge of other units. The governor was supposed to have a vice-governor and an assistant governor (tovarisch), while the voevoda had an assistant voevoda (tovarisch). The 
chancelleries were headed by a secretary, with a number of assistant secretaries and clerks who dealt with the paperwork. After the abolition of the hofgerichts and provincial courts, the judges - assessors - were also transferred to the chancelleries and became a part of the administrative system. Every chancellery had several departments (povyt'ia) dealing with different administrative areas. In criminal cases a voevoda or a governor made the final decision; in death penalty cases a voevoda's sentence had to be approved by a governor. Voevodas and governors also controlled magistrates (now renamed town halls - ratushi), which ruled on cases (except robberies and murders) between merchants and tradesmen. Magistrates functioned as a first instance for these social groups with the possibility of appeal to the voevoda or the governor.

It was Catherine's Statute for the Administration of the Provinces (1775) that brought a more or less consistent and independent court system into existence again. It was closely tied to the local and central administration. Russia was now divided into regions based on the population $(300,000-400,000)$. The emergent forty-one new regions (gubernii) were subdivided into districts (uezdy) with also approximately the same population size (20,000-30,000). The provinces (provintsii) were gone. The aim of the reform was to bring local government closer to the people in order to control and monitor the population. Each region received a governor as its head. Some regions received a governor-general (namestnik) with monitoring functions. Along with the general plan of bringing the authorities closer to the people, a whole new system of justice emerged. Catherine took the wishes of the nobility into consideration, eloquently expressed in the instructions to their deputies in the Legislative Commission of 1767: they demanded control over local administration and justice through the creation of collegial electoral bodies based on social divisions.

The new court system was firmly based on the principle that justice would be given in socially determined courts for each estate. At the same time, uniformed courts of appeal were established as well. The three major estates - nobility, townsfolk and state peasants - received two courts each: low and high courts (district land court (uezdnyi zemskoi) and high land court for the nobility; town magistrate and regional magistrate for the townsfolk; and low and high enforcement departments (pasprava) for state peasants). Three distinct terms signifying different structures were used to mark the different attitudes to justice: the nobility received the court (sud), a fully functional and relatively independent justice institution; the townsfolk continued to have magistrates, an all-ruling 
administrative body with judicial functions; and the state peasants were sent to the enforcement department (rasprava), originally oriented toward prosecution rather than justice as such. However, the judges in all these courts were supposed to be elected. These courts had jurisdiction over both civil and criminal cases, but had to transfer capital punishment cases for review (reviziia) at the regional (gunernia) level to the newly created House of Criminal Court (palata ugolovnogo suda), paired with the House of Civil Court (palata grazhdanskogo suda). The rulings of these Houses were final, subject to appeal to the Senate. On the district level another 'court' was created, a lower district (nizhnii uezdnyi) court. It had mostly police functions and was established to deal with small misdemeanours and the everyday policing of local districts.

\section{Making the Law Work: Trials}

This complex justice system worked fairly effectively in terms of procedure. It is commonplace in Russian historiography to distinguish between two types of procedure - sud (adversarial/accusatorial) and rozysk (inquisitorial) - with rozysk being prevalent in criminal procedure in the second half of the seventeenth and eighteenth centuries. It has also been noted that there was no clear division between civil and criminal procedure as such, at least until the administrative reform of 1775 . Chapter 10 of the Legal Code of 1649 (Ulozhenie) 'On the litigations' (the longest chapter of the code with 287 articles) regulated litigation in civil matters $(s u d)$, while chapter 21 'On Robbery and Theft Cases' provided a procedure for inquisitorial trials. The inquisitorial procedure was further developed by the Newly Promulgated Articles (novoukaznye stat'i) of 1669 and was allegedly decreed as being the only procedure in place by the ordinance of 1697.

Peter introduced the procedural law 'The Concise Description of Trials' (Kratkoe izobrazhenie protsessov) in 1716. It was then contrasted by the 1723 law 'On the Form of Trials' which brought the adversary procedure back. This provoked a major discussion about the continuity of the criminal procedure. However, Claes Peterson suggested that there was no contradiction here since Russian law never made a clear distinction between adversary and inquisitorial procedure. In addition, the 1716 law was mainly designed for the army and was probably limited in its use. Richard Wortman pointed out that Peter's design was not to change procedure as such, but to adjust it to the new situation by trying to bring the gentry into civil service. Later scholarship was tempted to see in the 1723 law the beginning 
of a new trend in the Russian judiciary, arguing that Peter tried to lay the foundation for using the adversary procedure only, but these illusions were criticized by D. O. Serov in his latest work in 2009. Serov did not doubt the prevalence of the inquisitorial procedure in Petrine Russia, and insisted that the 1723 law introduced simple formal requirements to unify trials. ${ }^{13}$

Muscovite lawsuits of the sixteenth and first half of the seventeenth centuries were adversary-type proceedings in which the two parties had primary responsibility for initiating the case, presenting the evidence, and adducing the arguments. The courts rarely summoned witnesses; judges seemed to have refereed the proceedings by ensuring that each party had a full opportunity to present its case. Occasionally, the court would carry out on-the-spot views and seek the submission of additional evidence. This evolved into an accusatorial type of trial that was used to deal with land disputes, material damage and other civil law matters. ${ }^{14}$ In an accusatorial trial, the judge acted as a mediating force to allow parties to present their arguments and evidence, to assess the evidence against the rules of trial, to make sure they presented witnesses or agree on the number of witnesses, to conduct cross examination and face-to-face confrontation if contradictory statements were presented, and to conclude the trial with a verdict that could be appealed all the way up to the Tsar.

At the time of the Ulozhenie there were three types of prosecutions: upravnye (punitive), sudnye (litigious) and sysknye (inquisitorial) cases. Upravnye (punitive) cases included punishment for an offence (pravezh) without a trial, in cases concerning the breach of government orders and instructions, or visible disobedience. These cases were mostly intended for the swift punishment of officials and clerks. Sudnye (litigious) cases were initiated by the petition of a plaintiff (chelobitnaia), could carry punishments such as temporary (short) imprisonment in the local jail or a monastery, corporal punishment, and monetary fines, and included an accusatorial type of litigation (for example, accusations of fornication, dishonour, petty theft, property damage). Sysknye (inquisitorial) cases were initiated either by the petition of a plaintiff or by a local official acting on the information received or on a report by a third party; they implied the death penalty or an equally severe punishment. These were cases of murder, robbery, and so-called political crimes (treason, lese majesty, blasphemy, and

\footnotetext{
${ }^{13}$ Claes Peterson, Peter the Great's administrative and judicial reforms: Swedish antecedents and the process of reception (Nordiska Bochhandeln 1979); Richard Wortman, 'Peter the Great and Court Procedure' (1974) 8 Canadian-American Slavic Studies 303-310; Serov, Sudebnaia reforma Petra I (n 12).

${ }^{14}$ George G. Weickhardt, 'Due Process and Equal Justice in the Muscovite Codes' (1992) 51 The Russian Review $463-480$.
} 
witchcraft when aimed at the tsar and his family). All three types could be found in the Ulozhenie of 1649 , and they all survived into the eighteenth century.

According to the law, there were rules on the application of inquisitorial methods. The inquisitorial procedure was almost never used in dishonour and other civil conflicts, while it was regularly used in the crime of lese majesty or other political crimes. The Legal Code of 1649 often used such formulae such as $i$ syschetsia pro to dopriama ('and it is fully established') or po sudu i po sysku ('by litigation and inquisition'), which meant that it was not the consistent inquisitorial procedure the lawmaker had in mind, but certain procedural methods to try certain cases. It is safe to assume that inquisitorial procedures were used in so-called political crimes and serious criminal offences (murder, robbery, rape, aggravated assault) and accusatorial procedures were used in civil cases and litigations over property, land, oral insults and minor physical injuries. It can be further argued that if the inquisitorial procedure was used to prosecute a certain offence, this was considered to be serious and threatening to the public order and state security, while the accusatorial procedure marked regular litigation cases. On the other hand, inquisitorial methods were required for prosecuting offences in which the establishment of guilt was not in the interest of an accused, or other evidence was hard to obtain. Thus. the inquisitorial procedure aimed at extracting evidence by torture to establish guilt, and finally to prosecute an offender. By nature, the inquisitorial procedure tended to result in the implication of the accused rather than in their acquittal.

The trial included three parts: 1) initiation of the procedure and investigation (initial complaint or report, establishing the circumstances of the case, defining corpus delicti, collecting evidence); 2) a trial which had to verify the investigation's results, assess evidence, establish guilt and rule a sentence; 3) execution of a sentence. ${ }^{15}$ There was no strict division between these parts of the criminal procedure before the 1775 administrative and court reform, after which investigation and execution became the duty of the police, while the trial was exercised by the courts. Previous to that, the same body - the regional or provincial chancellery - was in charge of all procedural stages. Both inquisitorial and accusatorial (or adversary) procedures went through the same stages but with technical differences, mainly concerning the use of torture and other interrogation methods.

${ }^{15}$ V. A. Linovskii, Opyt istoricheskikh rozyskanii o sledstvennom ugolovnom sudproizvodstve v Rossii (LekEst 2001, originally printed in 1849) 43. 
Appeal to the higher authorities and ultimately to the sovereign became one of the most commonly used strategies to combat judicial corruption and injustice in Early Modern Russia. The authorities, including the tsar, were overwhelmed with appeal petitions and regularly issued ordinances and laws to make the process more transparent, orderly and rapid. Amending the appeal legislation also allowed the authorities to strengthen the judicial hierarchy and to create a vertical power structure in the justice and administrative system, of which the tsar was the final appeal instance. Therefore, appeal represented one of the means against incorrect and unjust decisions, the means accessible to litigants. Another type of means to ensure due process and just decisions on behalf of the state was the revision of criminal cases.

In the Russian system of justice, appeal was originally reserved for cases in which judges were suspected of corruption and for this reason did not rule according to the law, or the litigants were dissatisfied with the court's decision. The Pre-Petrine appeal procedure worked in the following way: Moscow chancelleries were the first instance courts with appeal to the Boyars' Council (Boiarskaia Duma) and then to the sovereign. In criminal cases (murders and robberies), the first instance courts included so-called gubnye izby (investigation offices) with appeal to voevodas and to the Felony chancellery on the decisions of voevodas. The Boyars' Council and the sovereign acted as highest appellate bodies for the Felony Chancellery as for any other chancellery in Moscow. The system of ecclesiastical courts had a slightly more complicated appeal procedure. Local archbishop's chancelleries were the first instance courts with appeal to the archbishop and then to the Patriarchal Chancellery and the Patriarch himself.

Some scholars have expressed an opinion that there was no appeal for criminal cases tried through the inquisitorial procedure (because the procedure as such did not allow appeal), which allowed the police state to deal with the criminal situation swiftly and effectively. However, the ordinance of 1672 reconfirmed the appeal of criminal cases to the Felony Chancellery and stated that the imprisoned accused (kolodniki) should not be sent to Moscow to appeal, but that an extract of the case should be submitted instead. ${ }^{16}$ There were cases, however, when appeal was not possible. These involved two: when the case was settled in the arbitration court (Treteiskii sud), and when the case had been settled

${ }^{16}$ Serov, Sudebnaia reforma Petra I (n 12) 338-339. 
under the former (deceased) sovereign (this was especially important in political, corruption and property cases, when convicted officials and landowners petitioned the new tsar, complaining about the unjust ruling under his dead predecessor). At the same time, petitioning the tsar directly was prohibited under punishment (whipping for commoners, or a week-long imprisonment for the nobility). The only exclusion from this rule were charges of corruption of the judges, in which case petitioning the tsar directly was allowed. However, in cases of false accusations the petitioner was liable for the death penalty, since in cases of proven accusations, the judges were to be executed as well.

In this system the main concern was to acquire pravda, rather a complex combination of justice and truth, and which, understood as subjective justice, created a judicial mess: trials lasted years, chancelleries were overcrowded and overloaded with complaints, especially with appeal complaints and false accusations; corruption flourished. Peter I deemed that the only way to combat iabednichestvo (false accusations) was the re-introduction of the obligatory revision of cases. Revision supposedly made appeal unnecessary (or at least reduced the number of appeals) because the sentence was revised, and after careful checking of all the facts and compliance with legal procedures and laws, finally approved (or reversed). Peter introduced several supreme judicial bodies such as the Senate (the supreme court in all civil and criminal matters), later matched by the Synod (the supreme court in all ecclesiastical matters) and a separate supreme court (vyshnii sud), together with the Executive House (raspravnaia palata) and the Collegium of Justice. All these institutions had revision powers and were established as remedy bodies against the irregularities of the justice system. ${ }^{17}$

\section{Enforcing Moral Order: Canon law}

The Russian Church ruled according to the Apostolic and Church Fathers' canons, Byzantine legal codes and other canonical writings, all contained in the Kormchaia kniga. The Kormchaia was based on Byzantine ecclesiastical law and secular legislation. Byzantine ecclesiastical laws were translated into Old Russian in different compendia known as nomocanons. Usually such a nomocanon included fourteen titles and represented a concise edition of Byzantine codes. The Kormchaia in use between the sixteenth and eighteenth centuries originated in the thirteenth century with a translation from Serbian of

${ }^{17}$ On the procedure, see Nancy Shields Kollmann, Crime and punishment in early modern Russia (Cambridge University Press 2015); Marinna Muravyeva, 'Russian Early Modern Criminal Procedure and Culture of Appeal' (2013) 38 Review of Central and East European Law 295-316. 
the synopsis of the nomocanons. This Kormchaia did not include any of the original Russian ecclesiastical laws of the medieval period, utilizing only Byzantine codes and classical pre-schism canons.

Ecclesiastical justice belonged to the bishops and archbishops together with the Patriarch as the ultimate power of appeal in the sixteenth and seventeenth centuries. With the establishment of the Patriarchy, a slow reconfiguration of cathedrae (dioceses) had taken place since the late sixteenth century, the result being one Patriarchal cathedra, 13 metropolitans', 7 archbishops' and 2 bishops' cathedrae in 1700. The patriarchal diocese was managed by several chancelleries along with the Patriarchal chancellery to deal with judicial matters. It consisted of patriarchal boyars and other judges (d'iaki and pod'iachie) and ruled over the clergy and laity in both civil and criminal cases and in church matters within the patriarchal diocese. In 1667 the Moscow Church Council decided to add ecclesiastical judges to the chancellery's staff. Since they would deal with the clergy, the chancellery was divided into two departments: one for clergy and one for laity.

The Legal Code of 1649 and the Church council's decisions of 1667 clarified the ecclesiastical jurisdiction. Chapter XII of the Code stated that all lay people living on the Patriarch's lands should receive justice from the Patriarchal chancellery, while those from other lands and jurisdictions would have to litigate in the appropriate chancellery. The Church council of 1667 included the following cases in the ecclesiastical patriarchal jurisdiction: all litigation of the clergy; wills and testimonies; disobedience of children (XXII: 4, 5, 6); adultery; sexual abuse of serfs and other 'abuses' (XX: 80); 'abuse of wives and children of people of any rank'; disobedience and disorderly behaviour of parishioners; breach of church discipline (missing confession, not going to church etc.); slander (calling someone a bastard, fornicator or adulterer); beschect'e (dishonour) in the form of grabbing at someone's 'privy parts' (derznet rukoiu za tainye udy) or removing a female head-dress (oprostovolosit'); illegitimate children; corrupt marriages (within prohibited kinship degrees); divorces; adoption; runaway serfs if they married outside their owner's estate or entered the monastery; and litigations between Moscow inhabitants and the clergy from outside Moscow.

In other dioceses, clergy and laity attained justice in different ways. In monasteries, monks, nuns and the monastery peasants sought justice from the monastery authorities, especially if these monasteries 
(such as Troitskii, Voznesenskii and Novodevitchii) were given immunity by a special immunity act called nesudimaia gramota from the Patriarch or the Tsar. Some metropolitans and archbishops (Vologda and Novgorod) secured their authority by immunity acts as well. In general, according to these acts, the local bishop held jurisdiction over the clergy of his diocese. This jurisdiction, however, did not cover the capital criminal offences of murder, robbery, arson and theft. The bishop's jurisdiction resembled that of the Patriarch's in his own diocese. Patriarch Adrian, when explaining the diocesan jurisdiction to the archbishop of Kholmogory and Vaga, mentions more or less the same list of subjects as those covered by ecclesiastical jurisdiction.

The structure of ecclesiastical justice was quite simple and resembled the secular courts. Every archbishop was the ultimate judicial authority in his diocese; a monastery abbot (hegumenos) ruled over his monks and the peasant population on monastery lands. Where there were conflicts, the case could go up to the Patriarch's chancellery. Every archbishop or bishop had his own chancellery (dukhovnyi razriad), which consisted of several officials recruited from both clergy and laity. At the parish level, justice was managed by the local churchwardens, elected by the local community and subordinated to the appointed priest, who was present together with other authority representatives in the local chancellery office (prikaznaia izba). The bishop's chancellery also had a staff of bailiffs, recruited from the laity, and investigators (zakazchiki), recruited from the clergy, to conduct their own investigations.

However, this privileged situation ended with Peter I's ordinance to close down the Patriarch's chancellery and to transfer all civil and criminal cases involving the clergy and monastery peasants to the appropriate chancelleries. Although Peter abolished the patriarchy and submitted the Church de jure to the State by the creation of a collegial governing body called the Holy Synod (originally called the Spiritual Collegium) in 1721, the diocesan justice maintained its form in the eighteenth century. The Synod became the highest court in all ecclesiastical matters including the prosecution of the clergy, thus continuing the seventeenth-century policy of the church ruling over its own clergy. In the dioceses, the bishops maintained their power as an ultimate authority, but in the course of the century they became more and more dependent on the Synod. This was particularly true in the second half of the century when they were obliged to ask the Synod's approval for punishments they inflicted on both clergy and laity. By 1726 there was one metropolitan, eight archbishops', and eleven bishops' 
cathedrae in Russia, but all of these high officials were equal in status, despite the original plan to create a vertical hierarchy. The ecclesiastical chancelleries were converted into consistories or dicasteries (they could also be called (arch)bishop's houses (arkhiereiskie doma) or house offices or chancelleries). Each consistory in the first half of the century had 3-4 clerical judges, mostly recruited from monks or 'black' clergy as they were called due to their assuming black habits after joining monastic orders. There was a gradual increase in regular so-called 'white' clergy, that is those who did not chose to become monks and preferred to stay with 'lay' population serving as parish priest, in the offices as the century progressed. Before the 1760 s, all the paperwork was done by the chancellery under the supervision of the secretary, who was often a monk.

In 1722, Peter finally defined ecclesiastical jurisdiction in relation to criminal offences and the instances of ecclesiastical courts. The Church now had an authority that could prosecute for blasphemy, heresy, schism, witchcraft, sacrilege, corrupt marriages and divorces. In dealing with divorces, the consistory had to conduct a thorough investigation; that is, it would investigate offences such as adultery and its 'reasons', runaway spouses and unauthorized absences (this mainly applied to women as men, unlike women, did not have to ask their spouses' permission to go somewhere), bigamy and its reasons, forced marriages (coercion of children by parents and serfs by masters), forced taking of the veil (when husbands coerced their wives to take the veil in order to obtain not only a divorce but also their wives' property). All such cases, as well as complaints against the clergy regarding assaults, insults, theft and other petty crimes (including dishonour) had to be taken to the local consistories, while complaints against the bishops and monastery servants and peasants had to be addressed to their superiors. In case justice was not received or the decision was unsatisfactory, the complainant had to appeal to the local bishop. If the bishop's decision was not satisfactory, an appeal could be made to the Holy Synod. It was additionally confirmed that offences such as fornication, rape, rape of a serf woman by her owner, incest, raptus, illegitimate children, children born from incest relationships, and marriages without parents' approval should go to the state courts. The reconfigured jurisdiction of the church was now firmly established by state laws. The Synod also laid claim to extensive judicial authority over the clergy, securing ecclesiastical prosecution even in cases of capital offences of the clergy, which at first glance gave the church extra powers and strengthened it rather than weakened it in relation to the State. 
On the other hand, the Church failed to maintain jurisdiction over its own peasants and lay employees, who in 1727 were ordered to be tried and prosecuted in the regional and provincial chancelleries. Bishops became more dependent on the central authority (the Synod). They were not as free as in Muscovite times to punish their own clergy, as the Synod often overruled the local bishops' decisions. On the other hand, the State actively intervened in ecclesiastical jurisdiction: clergy guilty of political crimes or of initiating so-called 'word and deed' prosecution ('slovo i delo') were immediately arrested by the Preobrazhenskii Chancellery during Peter's reign and the Secret Office (Tainaia kantseliariia) from 1729. During Anna Ioannovna's reign (1730-1740) the government was greatly concerned about the level of superstition among the clergy; witchcraft became one of the crimes often transferred from ecclesiastical jurisdiction and tried in the state courts as a part of a 'word and deed' accusation or an independent charge based on the Legal Code of 1649.

In the course of the century, the structure of the ecclesiastical courts did not change much. Although they remained intact even after Catherine's reforms, the nature of ecclesiastical jurisdiction, however, was transformed significantly. The State started to use the spiritual authority of the Church rather than its prosecuting powers: it invited priests to admonish criminals, it used penances as additional punishments, and exploited the confessional practices. By the second half of the century, the Church tended to relinquish criminal investigations to the secular authorities, while it concentrated on corrupt marriages and divorces, and awarding penances to those convicted of criminal offences; this probably marked its finally becoming part of the State.

\section{The Legal Profession and Legal Literacy}

It is common for scholars to state that there was no evidence for a nascent legal profession as well as developed legal theory in the sixteenth and seventeenth centuries in Russia. This assumption is based on the absence of Western-type educational institutions such as universities with their faculties of law. However, this might not be the case in many European countries.

Russian legal education in the sixteenth and seventeenth centuries was incorporated into apprenticeship within a certain chancellery, which provided on-site training for future clerks that would lead them to obtain a license to be able to practice. The chancelleries often had their own schools. At the same time, 
more theoretical legal training was conducted in religious educational institutions as a part of specialisation in ecclesiastical law. The emergence of educational institutions in seventeenth-century Russia was closely connected with the pragmatic needs of the central government for skilled officials (working for both the State and the Church).

The Kievan Theological academy was founded in Kiev in 1615. In 1632, patriarch Filaret launched a Slavic-Greek school in Moscow to 'teach Greek to small children'. Another Moscow school appeared following the direct offer by Peter Mohyla to establish a school resembling the Kievan academy. This school, called the Andreevskii teaching monastery (uchilischnyi monastyr'), was founded in 1645-47 with the private money of Fedor Rtishschev (1626-1673), one of the outstanding statesmen of the era. Rtishschev invited several Ukrainian and Belorussian 'learned monks' as they were called to teach 'arts' together with theology at his private school. The lack of official state sponsored schools and academies in Muscovy was compensated for with a number of private schools maintained by both the clergy (often affiliated with monasteries) and nobility, as in the case of Rtishschev. They all contributed to the literacy of the population, which, as A. I. Sobolevskii insisted in the late nineteenth century, was quite high among the population, including peasants. Finally, the Slavic-Greek-Latin Academy in Moscow was launched in 1687, to be the first relatively comparable academic establishment to the higher educational institutions. ${ }^{18}$

These schools and academies did not train lawyers and neither was there any intention to study law; through religious education in theology, however, they established the firm tradition of the legal training. Therefore, by the time legal education was established in the second half of the eighteenth century, as well as when Russia started to receive foreign legal scholars during Peter's reign, there already existed a class of practising lawyers with legal training in both ecclesiastical and secular law.

The state via its legislation during this period discouraged the use of representatives in the courts. Lawyers, as private individuals who could manipulate the law, appeared as very dubious to both official and community eyes. Those who took on the task of representing litigants in the courts were usually marginal individuals in the judicial system, retired clerks practiced in the formalities of

\footnotetext{
${ }^{18}$ A. I. Sobolevskii, Obrazovannost' Moskovskoi Rusi XV-XVII vekov (Tipo-litografia A. M. Volfa 1892); B. L. Fonkich,
} Greko-slavianskie shkoly v Moskve v XVII veke (Iazyki slavianskikh kul'tur 2009). 
paperwork and informal rules of access to justice, or the serfs of wealthy noblemen trained to watch out for their masters' interests. The retired clerks often collaborated with their former colleagues in the chancelleries to the disadvantage of their clients, or worked for both parties in civil suits. ${ }^{19}$

Generally, what is assumed to be the absence of professional legal class mostly follows the model of the legal profession developed in some European countries such as England, Germany, Italy and France. For a variety of reasons, lawyers there emerged as mediators between the state and the people, and in connection with a separate judicial system, Russia did not have at the time. As noted earlier, the Russian court system was merged with administrative bodies and therefore there was no need for narrowly specialised lawyers as legal paperwork was considered to be a part of the general bureaucratic workload. In the system of Russian autocracy, it could be argued that any document was, in fact, a legal document. Therefore, administrative personnel was skilled in legal documentation, procedure, and well acknowledged with laws and numerous edicts, ordinances and instructions which guided the life of Muscovy.

Peter I took the ideas of scientific jurisprudence and a professional legal class very seriously. While he and his successors did not trust advocates or any private lawyers, they were concerned with the professional level of those who worked for the state. Besides organizing the system of legal training for practical purposes, Peter I also tried to contribute to the development of science as such and, probably under the influence of his correspondence with Leibnitz, realized the importance of legal theory in its philosophical interpretation. ${ }^{20}$ When the Academy of Sciences was established, Peter prescribed the teaching of history and law in its foundation charter and the cathedra was soon taken up by a German scholar, Christian Friedrich Gross (d.1742), who performed the duties of professor of moral philosophy until 1731, when he retired to enter the diplomatic service. Gross, a graduate of Tubingen, developed the Pufendorfian interpretation of natural law. At the same time, another German, doctor legens of the University of Königsberg, Johann Simon Beckenstein (d. 1774), took up the cathedra of public law (until 1735). Beckenstein took a very active part in teaching, research and practice. He was invited to be a member of the Collegium of Justice and Senate, to participate in the corruption trials and comment on the project of the new Ulozhenie in 1727. Another German scholar, Friedrich H. Stube de Piermont

\footnotetext{
${ }^{19}$ Wortman, Russian legal consciousness (n 4) 9-12.

${ }^{20}$ On this see G. S. Fel'dstein, Glavnye techeniia v istorii nauki ugolovnogo prava v Rossii (Tipografia Gub. Pravl. 1909) (hereafter Fel'dstein, Prava $v$ Rossii).
} 
(1704-1790), who took over from Beckenstein, was a Halle graduate and also performed different functions including participating in the legislation commission. All of these men developed their ideas within the natural law theory and, more specifically, widely used Christian Thomasius and Christian Wolff as their sources. When the faculty of law of Moscow University was founded in 1755 the professors (particularly Prof. Friedrich Dilthey, d. 1781) - both Russian and German - continued the tradition of using German legal textbooks. ${ }^{21}$

In connection with creating a separate judicial system, Peter was concerned with those who would now be called judges. He recruited those from the nobility pool or, to be more specific, from those nobles who wished to acquire a European education and supported Peter's Westernization. By 1725, the courts were staffed with 'new' men, all of them with some sort of Western-type education. However, administrative personnel continued to be recruited on the practical training basis. In addition, all Russian judges before Catherine II's Charter for Nobility had come from the military ranks, as Peter made military service compulsory. Therefore, their legal education and training often started with military (cadet) academies, which did have a compulsory course in law, which was taught by the professor from the Academy of Sciences. This situation started to change slowly after Moscow University was founded in 1755 with a separate faculty of law and the first graduates of the faculty entered state service in the late 1760 s. $^{22}$

\section{Building a Path to Modernity}

Russian law was undergoing a definite modernization which intensified in the seventeenth and, particularly, in the eighteenth century. The law became more rational, predictable and efficient. Russia actively engaged in codification and systematization of law, and that led to the more regular application of procedure and better lawyering. Russian law quickly adapted to the social, economic and political challenges, as it was under constant revision during the sixteenth, seventeenth and eighteenth centuries. ${ }^{23}$ The fundamental question is whether Russian law became modern in the sense of

\footnotetext{
${ }^{21}$ Fel'dstein, Prava v Rossii (n 20) 63-65; V. A. Tomsinov, Rossiiskie pravovedy XVIII-XX vekov: ocherki zhizni $i$ tvorchestva (Zertsalo 2007) I: 90-98.

${ }^{22}$ L. F. Pisar'kova, Gosudarstvennoe upravlenie Rossii s kontsa XVII do kontsa XVIII veka. Evolutsiia burokraticheskoi sistemy (ROSSPEN 2007).

${ }^{23}$ George B. Weickhardt, 'Modernization of Law in Seventeenth-Century Muscovy' in Jarmo Kotilaine and Marshall Poe (eds), Modernizing Muscovy: reform and social change in seventeenth-century Russia (RoutledgeCurzon 2004) 76-92.
} 

